\title{
IUELTAL
}

\section{Strategies to Improve Skills to Write Stories: A Case Study in Universities in Tulungagung City}

\author{
Dwi Astuti Nurhayati \\ English Department, IAIN Tulungagung \\ e-mail:dwiastuti507@gmail.com
}

Djatmika

English Department, Universitas Sebelas MaretSurakarta

e-mail:djatmika@staff.uns.ac.id

\begin{abstract}
:
The article discusses the quality of language exploitation performed by the students of the English Language Study Program in the City of Tulungagung in writing English text stories. The data was collected for 4 months, starting May up to August 2020 in IAIN Tulungagung campus in the sense of data collection, through the observation. This study used case study design and involves 43 Indonesian undergraduate students and who were majoring in English. Narrative texts produced by the students were collected to be analyzed using a qualitative approach. Two aspects becoming the focus of discussion are the text structure and the text texture. The former represents how discourse units are selected and arranged in accordance to the narrative format, while the latter is related to how grammar is exploited and how words are selected for the stories. The results show that most of the students are very good in selecting and arranging discourse unit to build the stories. Meanwhile, they still show weaknesses in constructing grammar and selecting words for the stories. In these areas, inferences from Indonesian and Javanese languages happen.
\end{abstract}

Keywords: discourse analysis, inference, stories, structure, texture

\section{Introduction}

Narrative texts can be used as indicators of English language skills of the authors (Cartledge \& Kiarie, 2001; Djatmika, et. al., 2012). This relates to the complete aspects of the linguistic 
features used to construct a text of that type. If several other types of factual texts tend to be built with the dominance of simple present tense for the verb, then a narrative text can accommodate various types of English tenses in it. Although the narrative part of this type of text will be presented in simple past tense, the inserted dialogs between characters can accommodate other types of tenses. In addition, narrative texts can also be written using various types of conjunctions in them - almost all types of conjunctions can be used to facilitate various types of logical relationships between clauses in such texts. This condition is not found in other types of texts - for example, a description or report text will not use temporal conjunctions or cause-effect conjunctions due to the purpose of the function of the text which does not require the conjunctions of these types.

In addition to the grammar quality outlined above, the texture of the narrative text that can demonstrate the language skills of the writer is the word choice. Like grammatical aspect, types of words exploited in a narrative texts tend to be more various than those which are selected for texts in other types. In summary, it can be said that the types of vocabulary used in other types of text will be used in a narrative text; conversely, some types of vocabulary used in narrative texts may not be found in other types of texts. For example, nominalization, abstraction, and technical terms can be exploited in any type of texts including in a narrative, whereas figures of speech, idiomatic expressions, or other connotative words/ expressions tend to be only used in narrative texts, and not in other factual texts such as in a procedure.

In addition to the grammar quality outlined above, the texture of the narrative text that can demonstrate the language skills of the writer is the word choice. Like grammatical aspect, types of words exploited in a narrative texts tend to be more various than those which are selected for texts in other types. In summary, it can be said that the types of vocabulary used in other types of text will be used in a narrative text; conversely, some types of vocabulary used in narrative texts may not be found in other types of texts. For example, nominalization, abstraction, and technical terms can be exploited in any type of texts including in a narrative, whereas figures of speech, idiomatic expressions, or other connotative words/ expressions tend to be only used in narrative texts, and not in other factual texts such as in a procedure.

Some studies related to writing stories had been conducted by some researchers such as: Asriani \& Handayani (2018), Mulyaningsih (2013), Hudri \& Ryanti (2015), and Pratiwi \& Rohmanurmeta (2018). Asriani \& Handayani (2018) conducted study on analyzing students' ability in writing narrative text at $8^{\text {th }}$ grade of SMPN 2 Tambangan. The result of the study explained that most of the students were unable in writing narrative text includes in content, organization, vocabulary, language use, and mechanics. Next, Mulyaningsih (2013) carried out study aimed to analysis students' ability in writing narrative text in terms of schematic structure and linguistic features from low, middle, and high achiever students of Junior High School in Bandung. The study revealed that the low and middle achiever students have insufficient knowledge of writing narrative, meanwhile the high achiever students have minor mistakes in writing narrative. Then, Hudri \& Ryanti (2015) also conducted study on students' ability in writing narrative text at second year students of MTs Nurul Jannah NW Ampena and achieved result that the grammatical and spelling errors, using connectors, vocabularies, and appropriate diction were the common difficulties of students. A study conducted by Pratiwi \& Rohmanurmeta (2018) also dealt with students' 
ability in writing short stories especially in using interactive multimedia based on the religious character of $6^{\text {th }}$ grade primary students. The study showed that the ability to write stories of $6^{\text {th }}$ grade students according to the religious character were good. In addition, some researchers also conducted study on improving and increasing students' ability in writing stories such as: Ranubumi, et. al. (2017), Yuhartanti, et. al. (2018), and Iftanti (2016). Ranubumi, et al. (2017) conducted study on improving students' writing short story skill through Time Token learning and video media on $7^{\text {th }}$ grade students of SMPN 5 Kediri. The finding covered that there was an increasing of students' mean scores in writing stories skills through Time Token learning and video media. Then, Yuhartanti, et al. (2018) employed study aimed to improved test-based short story writing skills in folklore through the use of audio-visual media in SMAN 1 Batang Anai. It discovered that short story writing skills through audio-visual media could improve. Iftanti (2016) in her article about improving students writing skill through writing journal articles declared that writing articles are essential to improve students' writing skills.

This current study focused on analysis the quality of university students' skills in writing stories according to the elements of writing stories included structure of text, sentence productivity, sentence structure, grammar, and word choice. Thus, the research question was formulated as: How is the quality of students' skills to write stories according to elements of writing stories?

\section{Literature Review}

Discourse units for a narrative text are classified into two such as obligatory and optional ones. The important one to be occurred is the obligatory units, i.e. orientation, complication, and resolution. Missing one of these units will destroy the function of the constructed text to be a narrative. In addition to these, some narrative texts may have one or two optional discourse units - evaluation and coda. The former precedes a resolution and the latter ends a story text. Meanwhile, the arrangement of these units in one text also varies. Many story texts may only have simple arrangement of discourse units such as orientation-complication-evaluation-resolution-coda, whereas others may have complicated one which is shown by repeated arrangement of complication-evaluationresolution-so a single orientation opens the texts followed by such a repeated arrangement and the text is then closed by a single coda (Djatmika, et. al., 2012; Santosa, et. al., 2006; Djatmika, -). Meanwhile, the quality of grammar exploitation and lexical selection represents the texture of the story texts (Djatmika, -; Gerot \& Wignell, 1995). A forwarded message is accommodated by a clause-consisting of a subject and a verb. If one language unit has two messages or more in it, then such a unit must be constructed by two clauses or more depending on the number of the message to become a complex sentence. These messages are the commodities of negotiation between participants in interaction. Furthemore, lexical aspects can be represented by word choice and also by language style. The former can be in the form of diction, while the latter is the way the writer present messages in style in one language. Meanwhile, related to the delivering of material in teaching narrative text, it is important to directly use English than Indonesian. According to Zainuddin, most Indonesian students tend to follow the Indonesian language sentence structure (Zainuddin, 2016). Using the first language structure in explaining problems related to culture and the difficult concepts of English structure can be helpful for English 
teachers and students, but it is considered not a good way to learn English (Agustin, et. al., 2015).

\section{Research Methodology}

Five narrative texts written by university students in Tulungagung were selected for the focus of analysis. The participants were 43 and taken from students of STKIP Tulungagung and IAIN Tulungagung. The students were asked to write a story text based on a series of pictures in the story book entitled frog, where are you? (Meyer, 1969). Data related to the texts's structure and texture were collected from the story texts. The former were in the form of discourse units and the way they are arranged to construct the narrative texts, while the latte were in the form of grammatical and lexical choice quality for the texts. The data were analyzed using qualitative approach. The collected data were then analysed to see the texts are produced to be narrative texts, and also to see how sentences were constructed and how words were chosen for the story texts.

\section{Findings}

All the texts produced by the students are constructed as narrative. All are built by arranging three obligatory units, i.e. orientation, complication, and resolution. No student exploit evaluation or coda as optional units for a narrative text. This probably is related to the fact that the texts were produced based on series of pictures - the students might focused to narrating the pictures rather than developing and improving them for a story text.

The other aspects that represent the language quality of the story books are grammatical and lexical matters. Each of these aspects shows the strength as well as the weaknesses of the authors which then will represents the general language quality of the books they have produced. The more grammatical mistakes and lexical weakness an author performs, the lower the language quality s/he has for her/ his book. The otherwise condition indicates good language quality for the book.

The quaility of the narrative texts texture will also show what areas of grammar and word choice that the university students still have problems, or what areas of grammar and word choice in which inferences from Indonesian or Javanese language still happen.

\subsection{Structure of Text}

Theoretically, a narrative text consists of three obligatory discourse units, i.e. orientation, complication, and resolution. In addition, two optional units can also be exploited to build such a text. As the writers composed the story texts based on a visual story book, in which they developed the text just by narrating panel by panel in the book, the produced texts then automatically become a narrative. The writers, actually, can make improvement for the texts by exploiting such optional discourse unit for their texts, but no writer did it. All of them just told the picture verbally without any additional units to complete their story texts.

\subsection{Sentence Productivity}

Five story writers have the ability to produce different numbers of sentences. The process of story writing was guided by a textless story book consisting of twenty two (22) picture panels. Therefore, if a panel is narrated in a sentence, then the story will be composed of twenty two sentences. A writer with good language skills tends to produce a lot of 
sentences because he will tend to narrate a panel in more than one sentence. Conversely, writers with low quality of language exploitation will tend to produce even fewer sentences than the number of panels. This can happen if several panels are summarized in one sentence only. For more details an example of one panel can be seen in the image below.

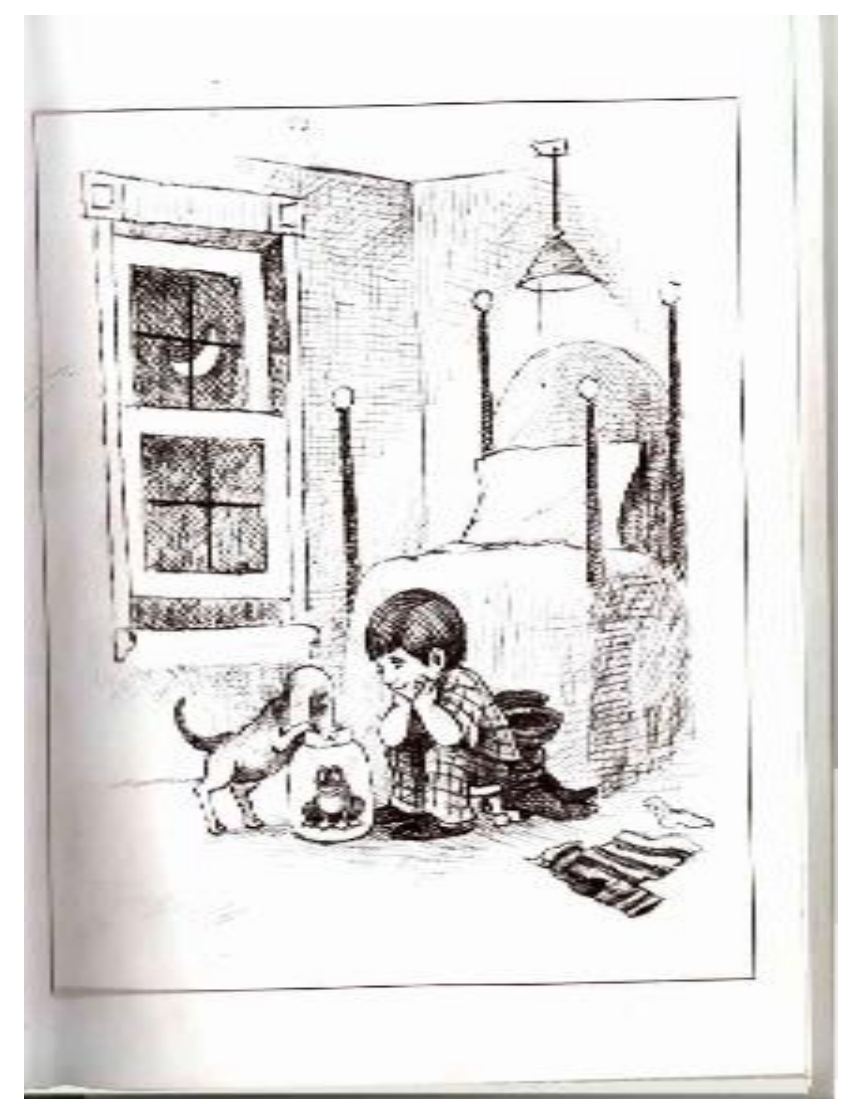

Figure 1

The figure above has many parts. With good English skills, a writer can describe the room as the setting of place, the time in which the event happening, the boy as well as the pet. Therefore, several sentences can be generated from one panel of this picture instead of just saying in one sentence "One day, a boy named John had a frog pet.", or in two sentences such as "One day, a boy named John found a frog. He put the frog in a jar". In connection with the production of this sentence, a student writer who has good English skills is able to produce 43 sentences from 22 picture panels in the storybook - on the other hand, another student with a very low performance is only able to produce five (5) sentences to narrate 22 of these panels. If other writers tend to narrate a picture in a sentence, this writer represents each picture in a phrase. Meanwhile, three other writers have an average ability to produce 23 sentences for 22 pictures in the storybook.

\subsection{Sentence Structure}

In addition to the sentence production, the grammatical skills of the student writers can also be represented by the types of sentence complexity. There are three types of complexity in English grammar, namely simple sentences, coordinating complex sentences, and subordinating complex sentences. The narrative texts that become the objects of the study 
have all three types of sentence complexity with different distributions and proportions between one text to the other, as displayed in the following table.

Table 1 Types of Sentence Structure

\begin{tabular}{|c|c|c|c|c|c|c|c|}
\hline & \multicolumn{2}{|c|}{ Simple } & \multicolumn{2}{|c|}{$\begin{array}{l}\text { Coordinating } \\
\text { Complex }\end{array}$} & \multicolumn{2}{|c|}{$\begin{array}{l}\text { Subordinating } \\
\text { Complex }\end{array}$} & \multirow[t]{2}{*}{ Minor } \\
\hline & Good & Bad & Good & Bad & Good & Bad & \\
\hline Text 1 & 17 & & 14 & & 11 & 1 & \\
\hline Text 2 & 8 & & 5 & 1 & 6 & 4 & \\
\hline Text 3 & & 1 & & & & 4 & \\
\hline Text 4 & 6 & 1 & 3 & & 13 & & \\
\hline Text 5 & 5 & 7 & 1 & 1 & 3 & 5 & 1 \\
\hline
\end{tabular}

The table above shows the skills of the student writers in constructing sentence structure in the story texts. Three types of construction can be made correctly by most of students, although few grammatical mistakes related to such a quality are still found. As the most commonly produced is subordinating complex sentences, then most of grammatical mistakes were made by the writers in this type of construction. However, a student shows very low grammatical skills. This author is only able to produce 5 sentences based on 22 picture panels-and not a single sentence is arranged grammatically. On the other hand, there is one writer who is able to produce three types of constructions with only a very small error. Therefore, we can suggest that the writer has had grammar capability in constructing simple and complex sentences.

\subsection{Types of Grammatical Mistakes}

Some types of grammatical mistakes are still made by the writers. Some types of mistakes happen in high frequency of occurrence, and conversely some others occurs in minimal numbers. Such types of grammatical mistakes can indicate the weak skill of the writers in exploiting English grammar rules for the sentence production. The types of grammatical mistakes made by the students are presented in the table below.

\begin{tabular}{|c|c|c|c|c|c|c|c|c|}
\hline \multirow{2}{*}{$\begin{array}{l}\text { Types of } \\
\text { Structure }\end{array}$} & \multicolumn{8}{|c|}{ Types of Grammatical Mistakes } \\
\hline & Tense & Art & pron & $\begin{array}{l}\text { S-V } \\
\text { agr } \\
\text { ee } \\
\text { me } \\
\text { nt }\end{array}$ & passive & $\begin{array}{l}\text { Incomple } \\
\text { te } \\
\text { Element }\end{array}$ & $\begin{array}{l}\text { Word } \\
\text { Order }\end{array}$ & $\begin{array}{l}\text { Plural } \\
\text { Agreemen } \\
t\end{array}$ \\
\hline Simple & 7 & 2 & & & 1 & 1 & & \\
\hline $\begin{array}{l}\text { Coordinating } \\
\text { Complex }\end{array}$ & 9 & 1 & 1 & & 2 & & & \\
\hline $\begin{array}{l}\text { Subordinatin } \\
\mathrm{g} \\
\text { Complex }\end{array}$ & 25 & 3 & & 8 & 2 & 9 & 1 & 4 \\
\hline
\end{tabular}

Five text stories written by students show 9 types of grammatical mistakes, with different distributions between one writer and another. The grammatical mistake with highest number of occurence is tense. This large number of tense mistakes implies that the most writers have weakness in this grammar area, and they get difficulty in choosing the type of tense according to what is needed by a context in the story text. As mentioned in the 
previous section, almost all types of tense in English can be used in a narrative text. This is due to the fact that narrative texts can contain fragments of dialogue with utterances that are accommodated by direct sentences - sentences that can allow each type of tense to be used. Meanwhile, the tense mistake that was most commonly done by the writers is the use of simple present tense in the narrating part, instead of simple past tense as shown in the example below.

1. He loves her frog so much.

2. Once upon a time, there is a boy who had pets, a dog and a frog.

3. The dog was okay but the jar is broken.

The three sentences above, each representing a type of sentence construction, are arranged in simple present tense. Because these three sentences are used to narrate events in the narrating part, and not as direct sentences in inserted dialogues, the type of tense used is less appropriate. Revising the type of tense to be simple past tense will make the text of the story more effective. In addition, several sentences with tense mistake also have grammatical mistakes in different types. The following sentences can show the case.

4. When the boy was falling the dog run past the boy.

5. The deer ran until the edge of the cliff but suddenly he stop and the little boy and his dog fell down in the pound.

The underlined part in the two sentences above is the verb in one of the clauses in such constuctions. The author of this sentence is inconsistent in the use of tense - in one part s/he correctly selected simple past tense, but in the other part the writer used simple present tense. Verbs which were selected incorretly in simple present tense even also show mistakes in Subject-Verb agreement.

The other type of mistakes made by most of the writers is the use of article. Several types of incorrect article exploitation for the story texts are presented in the following examples.

6. Rudy and dogy look for beloved frog on all side of the room.

7. One night, while a little boy and his dog were sleeping, the frog climbed out of the jar and it went out through the open window.

8. In a night day, there was a children and her pet, the dog and frog in the jar, he was very happy and then he go to get up with her dog.

The three sentences above represent three types of grammatical mistake related to English articles. The first sentence shows the absence of an article for the word frog. Because this sentence appears after the frog character has been used in the previous section, in this sentence such a character must go with an article of the. Similarly, the second sentence is positioned after a few opening sentences. However, the grammatical mistake is the wrong selection of article, whereas the third sentence exemplifies the use of an incorrect and actually unnecessary article. The word children is a plural noun, and this sentence appears at the beginning of the story, the use of article a for the word children has a double mistakesthis article does not agree with the noun, and actually this article does not need to be present in that context. 
The remaining types of grammatical mistakes are those in the area of pronoun, passive voice, short of grammar components, word order, and plural agreement. These mistakes were minor. They were only performed by the writers in several clauses. Meanwhile, a writer produced the only one mistake in using pronoun. In telling that the boy in the story looked for his missing dog, he then wrongly referred the boy with the pronoun I-in which in this case this pronoun refers to the writer and not the boy as the main character in the story. The case is presented in the sentence of "The boy looked everywhere but I couldn't find his frog." The other minor grammatical mistake is the incomplete components for a clause. The writers might miss a subject, a verb, or a conjunction in the sentence construction, as seen in the following examples.

9. The boy searched everywhere in his room but could not find the frog.

10. Till finally there is a hole maybe its where the frog is hiding.

11. To the out side of the room to the out side of the house.

Each of the three sentences above shows the incomplete components with different types. The presence of conjunction but, the first sentence should be constructed in a coordinating complex construction. However, this construction misses a subject for the verb could not find, so that this make such a construction less grammatical. Meanwhile, the second sentence can actually present several types of mistakes--one of which is the incomplete component. The first mistake of this sentence is the presence of the conjunction till that begins the sentence. This type of conjunction is never present to begin a sentence - this is commonly positioned in the middle of two clauses being combined, such as in the sentence "He searched the frog everywhere until he found a hole". The other mistake of this sentence is the presence of the words maybe and its which actually damage the grammatical quality of this construction. If the sentence is said to be "Finally there is a hole where the frog is hiding", by deleting the two words, then this new construction looks more effective and acceptable, although there are still other errors that occur, namely tense. If the presence of the word maybe is meant to accommodate the meaning of probability through a modal operator, then the word maybe could be changed for might and used to replace the word is: "Finally there was a hole where the frog might hide". Meanwhile, the third sentence is a minor clause. Although this construction is used to deliver a message, this language unit is not a clause as no predicating part exist in the construction.

In the meantime, the story writer also made a mistake in constructing passive sentences with incorrect grammatical forms. There are two wrong forms of grammar, namely the passive form without auxiliary verbs, and the passive form that is not needed. These two forms of error are contradictory - the first occurs because the writer missed an auxiliary verb to construct a passive voice for his sentence, while the second mistake occurs when the writer used an unneeded auxiliary for a verb which should be expressed for an active voice. The following sentences might exemplify those two cases.

12. The jar broke and the dog's head was not stuck anymore.

13. The boy was screamed for help but no one comes to help him.

The verb broke in the first sentence above should be delivered in a passive voice. Thus, grammatically this construction still requires an auxiliary to be completely said as "The jar was broken and the dog's head was not stuck anymore." Conversely, the verb was screamed 
in the second sentence should be expressed in an active voice, and not passive voice, because the context of the sentence requires that type of voice. Thus, this construction actually has unneeded auxiliary that must be removed in order to more effectively convey the messages.

\subsection{Word Choice}

In addition to grammar quality, the authors also showed some mistakes in choosing diction for the text of their stories. Two of these mistakes can be seen in the examples below.

14. Suddenly an owl came out of the hole and attacked the boy until he was pressed next to a large rock.

15. He asked his dog to be quite.

The italic part in each of the two sentences above is not clearly understood. This is related to the incorrectly used words and expressions. The expression was pressed next looks not commonly used in English. The writer seemed to say "An owl came out of a hole and attacked the boy until he was cornered near a large rock." If this is what the writer wanted to say, then the pressed next to a large rock can be expressed as was the cornered at the large rock. Meanwhile, the bold words in the other sentence might be chosen with wrong spelling. The writer should say to be quiet but wrongly he wrote quite.

In connection with the choice of expressions and vocabulary for the text of the story, several language styles are also found. Some expressions were made by writers in the Indonesian style instead of English. Two of the expressions can be seen in the two sentences below.

16. One day, live in small house a boy named Rudy and his beloved dog and frog.

17. How shocked the boy was when he saw the jar open and there was no frog in the jar.

Because the message of the two sentences was delivered in the Indonesian language style, the two examples above experienced grammatical errors. The first sentence appears to have an incorrect word order. An inversion was done by the writer for the context of the sentence which does not require it - the same case also occurs for the second sentence. That happened because the writer presents the message of the two sentences not in the English, but in the Indonesian style. The word order of the two sentences above shows that the writer actually wants to say the following:

18. Pada suatu hari, hiduplah di sebuah rumah yang kecil seorang anak bernama Rudy dengan anjing dan katak kesayangannya.

19. Betapa kagetnya anak itu ketika dia mengetahui toplesnya terbuka dan tidak ada katak di dalam toples itu.

According to the above analysis, the way to improve students' skills to write stories was by representing the provided pictures into stories. Students also could write by creating their own stories based on the pictures.

\section{Discussion}

There are two aspects of narrative text that can represent the English language skills of English study program students in Tulungagung Regency. The first aspect is related to the 
structure of the text or the format of the narrative text that they build, while the second aspect is the grammatical skills and vocabulary selection for the story text. Although the writers are able to construct their story texts correctly, the discourse units used are only limited to the obligatory ones. They do not dare to try to use units that are optional, namely evaluation and coda. The results of the students' ability in writing narrative texts in terms of content organization, vocabulary, language use, and mechanics are still below the minimum criteria. Some of them have limitations understanding of vocabulary, grammar, and tenses. (Hasibuan \& Handayani, 2018). Next in terms from multiple level achievements have different abilities in applying traits in the story. For example, students who are low achievers have less knowledge of language features narration. Medium achievers have a better understanding and high achievers have a good uderstanding of the features of narrative language. (Mulyaingsih, 2013).

Meanwhile, the writer's skill in grammar exploitation is still not optimal. There are several aspects of English grammar that show the weaknesses of the writers. In addition, they also made mistakes in choosing vocabulary and in presenting expressions in the English style. Meanwhile, according to statement that the more complicated the structure, the more difficult it is for students to write English sentences (Maisaroh, 2010). This is a concern occurred in Indonesian students as English as foreign language that style in writing sometimes become difficult to be created. Yuhartanti, et.al (2018) claimed that the student's low ability in writing could be seen from the less knowledges of students in writing, the paper's quality of students is not good, theres is no enthusiasm in following writing communities or training, and also the less creativity during writing.

Actually, there are many techniques to improve students' ability in writing. According to the research had been conducted by Yuhartanti, et.al (2018), factors affecting the improvement of the learning to write a short story by used audio-visual media can increase the students' motivation in learning. The similar research also conducted by Ranabumi at.al (2017), he proved that the use of the Time Token learning model and video media can improve student's short story writing. Besides, writing journal articles is also the best choice in improving students' writing skills. Based on the research of Iftanti (2016), the benefit of writing journal article can improve the students' writing skills and help their works much beneficial.

In addition, there are several expressions that are conveyed in the Indonesian language style. This Indonesian language style can at the same time show the inference of the Indonesian language to the use of English, in addition to the lexical inference shown by the previous examples (Nurhayati, et. al., 2018). Meanwhile, inference in grammatical form can be represented by tense errors, completeness of elements, and word order. In connection with this condition, the strategies that can be suggested are activities in the form of training I learning to write story texts by understanding the types of discourse units that must be present and can be optional ones that can be used to compose a narrative text. In addition, training is also focused on grammatical and vocabulary weaknesses.

\section{Conclusion}

Of the two aspects of narrative text produced by students, the texture of the text becomes part of the need for more intensive training. Grammar areas that are less mastered by students need to get a deeper portion of the material or syllabus of learning in the class. In 
addition, strengthening the mastery of English vocabulary also needs to be done for students so that the vocabulary selection skills for story text get improved. Meanwhile, by observing the pictures, students could possibly improve their writing stories skill. By pictures, they could arrange sentences based on their own ideas to be written stories.

\section{References}

Agustin, T. D, Warsono, \& Mujiyanto, J. (2015). The use of Bahasa Indonesia (L1) in the intensive English (L2) classroom. English Education Journal, 5(1), 1-9.

Asriani, H. and Handayani, F. (2018). An Analysis of Students' Ability in Writing Narrative Text (A Study at the $8^{\text {th }}$ Grade of SMPN 2 Tambangan) in 2018/2019 Academic Year. MELT Journal, 3(1), 55-63.

Cartledge, G. \& Kiarie, M. (2001). Learning Social Skills through Literature for Children and Adolescents. Teach. Except. Child., 34(2), 40-47.

Djatmika. (-). Kualitas Olah Bahasa Anak Usia Sekolah Dasar dalam Kegiatan Bercerita: Sebuah Proses Pemerolehan Bahasa Anak. Met. J. Penelit. Bhs., 10(2), 1-2.

Djatmika. (-). Systemic Strategies to Modify the English Version of Javanese Folklore. Indones. J. Syst. Funct. Linguist., 1(2).

Djatmika, Khrisna, D.A., \& Nuraeni, A. (2012). Systemic strategis to improve the readability of the English version of Indonesian children stories. KATA, 14(2), 43-51.

Gerot, L. \& Wignell, P. (1995). Making Sense of Functional Grammar. Cammeray: AEE.

Hudri, M. and Ryanti, N. (2015). Analysis of Students' Ability in Writing Narrative Text. Jurnal ProdiUniversity of Muhammadiyah Mataram, 19-31.

Iftanti, Erna. (2016). Improving Students' Writing Skill through Writing Journal Articles. Lingua Scientia, 8(1).

Maisaroh. (2010). Common grammatical errors made by beginner level students: A study of language interference. Retrieved March 2020 from http://download. portalgaruda.org/article. php?article $=116426 \&$ val=5329.pdf

Meyer, M. (1969). Frog, where are you?. New York: Penguin Putnam Inc.

Mulyaningsih, Dini U. (2013). An Analysis of Students' Ability in Writing Narrative Texts (A Case Study at One Public Junior High School in Bandung). Journal of English and Education, 1(2), 16-22.

Nurhayati, D. A. W.., Djatmika, Santosa, R. \& Wiratno, T. (2018). Exploring Indonesian interference on morpho- Syntactic properties by Javanese speakers: A case study of English lecturers and students' interaction in two colleges in East Java, Indonesia," Pertanika J. Soc. Sci. Humanit., 26(T).

Pratiwi, Cerianing P. and Rohmanurmeta, Fauzatul M. (2018). Analysis of Short Story Writing Skill by Using Interactive Multimedia Based on the Religious Character of Students Primary School Grade 6. MUADDIB: Studi Kependidikan dan Keislaman, 8(2), 90-98.

Ranubumi, R., Rohmadi, M., and Subiyantoro, S. (2017). Improving Students' Writing Short Story Skill through Time Token Learning and Video Media on Grade VII Junior High School. Journal of Education and Learning, 11(4), 439-445.

Santosa, R., Djatmika \& Primasita, F.A. (2006). Sastra Anak Sebagai Wahana Pengenalan dan Pengasuhan Ideologi: Sebuah Kajian Wacana. J. Penelit. Hum Special Ed. 
Dwi Astuti Nurhayati \& Djatmika

Yuhartanti, Juita, N., and Asri, Y. (2018). Increasing Writing Skills in Text Based Short Story (Folklore) through Audio Visual Media. International Conference on Language, Literature, and Education (Advances in Social Science, Education, and Humanities), 263, 281-285.

Zainuddin, Z. (2016). Morphosyntactic analysis on Indonesian EFL learners' descriptive writing. Lembaran Ilmu Kependidikan, 45(2), 47-55. 